NBER WORKING PAPER SERIES

\title{
ALCOHOL ADVERTISING AND ALCOHOL CONSUMPTION BY ADOLESCENTS
}

\author{
Henry Saffer \\ Dhaval Dave \\ Working Paper 9676 \\ http://www.nber.org/papers/w9676

\section{NATIONAL BUREAU OF ECONOMIC RESEARCH 1050 Massachusetts Avenue Cambridge, MA 02138}

May 2003

The authors would like to thank Michael Grossman for his helpful comments. This project was funded by Grant Number R01 AA11851-02 from the National Institute on Alcohol Abuse and Alcoholism to the National Bureau of Economic Research The views expressed herein are those of the authors and not necessarily those of the National Bureau of Economic Research.

(C)2003 by Henry Saffer and Dhaval Dave. All rights reserved. Short sections of text not to exceed two paragraphs, may be quoted without explicit permission provided that full credit including Cnotice, is given to the source. 
Alcohol Advertising and Alcohol Consumption by Adolescents

Henry Saffer and Dhaval Dave

NBER Working Paper No. 9676

May 2003

JEL No. I1

\begin{abstract}
The purpose of this paper is to empirically estimate the effects of alcohol advertising on adolescent alcohol consumption. The theory of brand capital is used to explain the effects of advertising on consumption. The industry response function and the evidence from prior studies indicate that the empirical strategy should maximize the variance in the advertising data. The approach in this paper to maximizing the variance in advertising data is to employ cross sectional data. The Monitoring the Future (MTF) and the National Longitudinal Survey of Youth 1997 (NLSY97) data sets, which include only data for adolescents, are employed for the empirical work. These data sets are augmented with alcohol advertising data, originating on the market level, for five media. Use of both the MTF and the NLSY97 data sets improves the empirical analysis since each data set has its own unique advantages. The large size of the MTF makes it possible to estimate regressions with race and gender specific subsamples. The panel nature of the NLSY97 makes it possible to estimate individual fixed effects models. In addition, very similar models can be estimated with both data sets. Since the data sets are independent, the basically consistent findings increase the confidence in all the results. The results indicate that blacks participate in alcohol less than whites and their participation cannot be explained with the included variables as well as it can for whites. A comparison of male and female regressions shows that price and advertising effects are generally larger for females. Models which control for individual heterogeneity result in larger advertising effects implying that the MTF results may understate the effect of alcohol advertising. The results based on the NLSY97 suggest that a compete ban on all alcohol advertising could reduce adolescent monthly alcohol participation by about 24 percent and binge participation by about 42 percent. The past month price-participation elasticity was estimated at about -0.28 and the price-binge participation elasticity was estimated at about -0.51 . Both advertising and price policies are shown to have the potential to substantially reduce adolescent alcohol consumption.
\end{abstract}

\section{Henry Saffer}

National Bureau of Economic Research

365 Fifth Avenue 5th floor

New York NY 10016-4309

hsaffer@gc.cuny.edu
Dhaval Dave

National Bureau of Economic Research

365 Fifth Avenue 5th floor

New York NY 10016-4309

ddave@gc.cuny.edu 


\section{Introduction}

Public health advocates have expressed concern that alcohol advertising is a factor contributing to adolescent alcohol consumption. Both the level of alcohol consumption by adolescents and the level of alcohol advertising are considerable. Data from the 2001 Monitoring

the Future Surveys (MTF) show that 7.7 percent of $8^{\text {th }}$ graders, 21.9 percent of $10^{\text {th }}$ graders and 49.8 percent of $12^{\text {th }}$ graders consumed alcohol within the past 30 days (Johnston, O’Malley, Bachman, 2002). A Federal Trade Commission (FTC) report (1999) documents several outcomes associated with underage drinking. These include reduced educational attainment, increased fatal motor vehicle crashes, increased suicide attempts and increases in sexually transmitted diseases. The probability of alcohol problems in adulthood also increases as the age of alcohol onset decreases. Competitive Media Reporting (CMR) estimated that alcohol producers spent about $\$ 1.5$ billion on measured media advertising in 2001. This was a 25 percent increase over spending in 1998. Alcohol industry reports to the FTC suggest that measured media advertising account for only one half to one third of total promotional expenditures. Other forms of alcohol promotion include: sponsorships; internet advertising; point-of-purchase advertising; consumer novelties; product placements in movies and TV shows; direct mail; price promotions; and trade promotions directed at wholesalers and retailers. These expenditures may enhance the effectiveness of measured media spending.

Although there is a considerable level of alcohol advertising, the alcohol industry argues that its advertising codes prohibit content and placement of advertising which target underage individuals. The advertising codes require that more than 50 percent of the exposed audience be over 21. The advertising codes also prohibit use of actors who appear underage and prohibit the use 
of Santa Claus. Cartoon characters, however, are not restricted and beer advertisers have no restrictions on the use of sports celebrities. ${ }^{1}$

The Center on Alcohol Marketing and Youth (2002) examined the exposure of youth to alcohol advertising in magazines, on TV and on radio. Youth are defined as individuals under the age of 21 . They found that in 2001, advertisers delivered 45 percent more beer advertising to youth than to adults in magazines. For spirits, 27 percent more magazine advertising was delivered to youth than to adults. However, for wine youths saw 58 percent less advertising than adults. Young adults, defined as ages 21 to 34, were exposed to slightly more magazine alcohol advertising than those under 21. Adults over 34 were exposed to the least amount of alcohol advertising in magazines. They also found that on TV underage youth were exposed to two beer or ale ads for every three seen by an adult. Beer and ale ads on TV represent about half of all alcohol advertising in all media. On radio, youth heard 8 percent more beer and ale advertising, 12 percent more malternative advertising and 14 percent more advertising for distilled spirits than adults 21 and older. Youth heard substantially less radio advertising for wine. Grube (1995) reviews research on the effect of alcohol advertising on knowledge, attitudes and intentions to drink by adolescents. He finds that much of the imagery in alcohol advertising does appeal to youth and that this advertising increases positive expectations about alcohol.

Studies of advertising exposure has led some public health groups to conclude that there is a link between advertising and adolescent alcohol consumption. The Robert Wood Johnson Foundation (1999) concludes that alcohol advertising and marketing are factors in the environment that help create problems of underage drinking. There is, however, very little empirical evidence that alcohol advertising has any effect on actual alcohol consumption (see for example, Nelson,

\footnotetext{
${ }^{1}$ The beer, wine and spirits industries each have a somewhat different advertising code.
} 
1999 or Fisher, 1993). Although both the level of alcohol consumption among adolescents and the level of alcohol advertising are substantial and well documented, the link between the two remains a controversial subject. There are no econometric studies of the effect of alcohol advertising on adolescent drinking. The purpose of this paper is to provide these empirical estimates. The empirical models include gender and race specific regressions of the effect of alcohol advertising.

\section{Theoretical Framework}

Competition through advertising, rather than price, is often preferred in industries that are highly concentrated, such as the alcohol industry. ${ }^{2}$ Schmalensee (1972) shows that oligopoly firms are likely to advertise more than similar firms in monopoly situations. Oligopoly firms attempt to increase their share of the market with advertising rather than with price competition. Each firm will be reluctant to use price competition if they believe that their rivals will also cut price. If all firms cut price, they all move down an inelastic demand function similar to the industry demand function. Share of market will not increase and revenue will decline. Advertising research usually finds that the firm with the largest share of voice has the largest share of market. ${ }^{3}$ Each firm attempts to advertise more than their rivals, which results in a high level of industry advertising. The advertising-to-sales ratio for the alcohol industry is about nine percent, while the average for all industries is about three percent (Advertising Age, 1999).

Becker and Murphy (1993) argue that advertising can be viewed as a complement to the advertised good. They define the complementary good as a favorable image about the advertised good. This increases the marginal utility of consumption and thus increases demand. Becker and Murphy's concept can be expanded somewhat and placed in the context of advertising theory. Since advertising has a cumulative effect, the complementary good can be described as a stock and

\footnotetext{
${ }^{2}$ This is less true for wine than for beer and spirits.
} 
in advertising theory is called brand capital. Brand capital is defined as the collective positive associations that individuals have about a brand. Advertising is one method of adding to or altering brand capital. Brand capital depreciates over time and at differential rates for different brands. As brand capital depreciates, a firm can attempt to offset the resulting decreases in sales with the creation of additional brand capital. Depending on the relative marginal costs and marginal benefits, the additions to brand capital can come in the form of new brands or from changes in the content and level of advertising for existing brands. If advertising were banned, there would only be limited possibilities to offset brand capital depreciation. This would reduce the marginal utility of consumption and reduce sales.

Empirical studies of alcohol advertising estimate an alcohol demand equation. The alcohol demand function is derived by assuming that a consumer maximizes a utility function, which includes alcohol as one of its arguments, subject to a budget constraint. The complementarity of brand capital suggests that alcohol advertising will increase the marginal utility of alcohol and thus increase demand. This optimization problem results in an equation which shows that the demand for alcohol is a function of alcohol price, alcohol advertising, and other variables affecting alcohol demand such as income, availability of alcohol, alcohol sentiment and other taste variables. Aggregating across consumers results in the market demand function.

Economic theory predicts that the relationship between advertising and consumption is subject to diminishing marginal product. This concept is the basis of the advertising response function. Advertising response functions have been used in brand level research to illustrate the effect of advertising on consumption at various levels of advertising. Economic theory suggests that due to diminishing marginal product, advertising response functions flatten out at some point.

\footnotetext{
${ }^{3}$ Share of voice is the firm's advertising as a percent of total industry advertising.
} 
That is, after a certain point consumption becomes ever less responsive to increases in advertising. Ultimately consumption is completely unresponsive to additional advertising. Brand level empirical work on beer advertising clearly supports this diminishing marginal product assumption (Rao and Miller, 1975; Ackoff and Emshoff, 1975). One important implication of diminishing marginal product is that, since media are not perfect substitutes, media diversification is necessary to maximize the effect of a given advertising budget. This point can also be made with respect to other forms of promotion.

The same theory which describes the brand level advertising response function can be applied to the product level. The product level is defined as all products produced in the industry. For example, the product level for alcohol would include all brands and variations of beer, wine and spirits. The product level advertising response function is similar to the brand level function and is graphed in figure 1. The vertical axis measures product level consumption and the horizontal axis measures product level advertising. The product level response function is different from the brand level response function in that advertising-induced sales must come at the expense of sales of products from other industries. Increases in consumption come from new consumers or from increases by existing consumers. New consumers are often adolescents who are uninformed about the true costs and benefits of alcohol consumption.

The two response functions represented in figure 1 and in figure 2 help to illustrate the likely outcome of alternative methods of measuring advertising. There are three methods of measuring advertising used in econometric studies of advertising and total consumption. These three categories are: 1) studies which use annual or quarterly national aggregate expenditures as the measure of advertising, 2) studies which use cross sectional measures of advertising and 3) studies 
of advertising bans. Table 1 provides a brief summary of the data and results from prior empirical studies of alcohol advertising.

The most common type of study uses a time series of national expenditures as the measure of advertising. National advertising expenditures are the total of all alcohol advertising expenditures, for all advertisers, in all media, for all geographic market areas. This is a high level of aggregation of the advertising data and as a result the data have very little variation. Since alcohol is heavily advertised, the marginal product of advertising may be very low or zero. In figure 1 , this is equivalent to measuring advertising in a small range around $A_{1}$. The loss of variance due to national aggregation leaves little to correlate with consumption and since the advertising occurs at a level where the marginal effect is small, it is not likely that any effect of advertising will be found. As table 1 indicates, very little effect of advertising is found by such studies.

A far less common type of study uses cross sectional data to measure alcohol advertising. This type of study is less common since the data are more difficult to acquire. Cross sectional data can differ but would typically be local level, such as a Metropolitan Statistical Area and has greater variation than national level data for several reasons. One reason for variation in advertising levels is that the cost of advertising varies across local areas. This is illustrated in figure 2 by the three data points $\mathrm{Am}_{1}, \mathrm{Am}_{2}$ and $\mathrm{Am}_{3}$. An econometric study which uses local level data would have potentially larger variation in advertising levels and in consumption. When the data are measured over a relatively larger range, there is a greater probability of being in an upward sloping portion of the response function. Local level advertising data are thus more likely to find a positive relationship between advertising and consumption. As table 1 indicates this type of study finds a positive effect of advertising. 
The third category of studies is based on alcohol advertising bans. The potential effect of a ban on certain media is shown as a downward shift of the response function in figure 1. An advertising ban may not reduce the total level of advertising but will reduce the effectiveness of the remaining non-banned media. The reason for this is as follows. A ban on one or more media will result in substitution into the remaining media. However, each media is subject to diminishing marginal product. The increased use of the non-banned media will result in a lower average product for these media. This shifts the response function downward. Firms may or may not respond to this decrease in effectiveness of their advertising expenditures. Firms may try to compensate with more advertising which would be illustrated by moving to a higher level of advertising on a lower advertising response function. ${ }^{4}$ Firms might increase the use of other marketing techniques such as promotional allowances to retailers. As indicated in table 2 this type of study has found that advertising bans do reduce alcohol consumption.

3. Data

The first data set employed in this study is the Monitoring the Future surveys (MTF). The MTF data used in this study are a pool of the 1996 and 1998 cross sections of $8^{\text {th }}$ graders, $10^{\text {th }}$ graders and $12^{\text {th }}$ graders. ${ }^{5}$ This pool is a nationally representative sample of over 63,000 high school students. The pooling of the 1996 and 1998 surveys provides sufficient samples for separate analysis of the effects of alcohol advertising by race and gender. This is interesting since there may be differential effects of advertising by race and gender. Pooling these two years also provides an additional time variance in the alcohol advertising and price variables.

\footnotetext{
${ }^{4}$ In a simple model, the decrease in marginal product would reduce the use of the input. However in an oligopoly model, with response to rivals, one reaction to reduced sales is to increase advertising.

${ }^{5}$ A special version of the MTF data which merged advertising and prices to individual records was made available to this project. This special data set contained only a limited number of individual specific variables.
} 
The MTF surveys provide data on drinking occasions in the past year as well as the past month and the number of times in the past two weeks that the respondent had five or more drinks in one occasion. Three dichotomous alcohol participation variables were constructed from these data. These are past year participation, past month participation and binge participation. The binge drinking variable is defined as one if the youth had at least one drinking occasion in the two weeks prior to the survey in which five or more drinks were consumed, and is zero otherwise. Binge drinking represents those occasions most likely to have negative consequences and to be of concern to policy makers (i.e., drinking five or more drinks in a single occasion and then driving is expected to significantly raise the probability of a motor vehicle accident and, potentially, death).

Several independent variables were constructed from the socioeconomic and demographic questions included in the surveys. These variables are: the individual's income, gender, age and race (white, black, Hispanic or other) ${ }^{6}$. The regressions also include a single time dummy. Table 2 provides summary definitions and means for the variables which were used in the regressions with the MTF data.

The second data set employed in this study is the National Longitudinal Survey of Youth 1997 (NLSY97). The sample consists of approximately 10,000 youths who live in the US and who were 12 to 16 years old as of December 31, 1996. Using a statistically selected representative sample of all households, based on the 1990 Census, the sample is representative of adolescents nationwide. The NLSY97 data provide an important alternative to the MTF by including individuals who are not in school and by including data collected from the parents. It is also a panel data set, which allows for estimation of individual fixed effects models. The NLSY97 data set used for the regressions was constructed from the 1997 and 1998 panels. 
The NLSY97 surveys provide data on alcohol consumption and basic demographics. The alcohol variables include past month alcohol participation and binge participation. Binge participation is defined as one if the youth had at least one drinking occasion during the 30 days prior to the survey in which five or more drinks were consumed, and is zero otherwise. The independent variables constructed from the demographic questions include the individual's income, gender, age and race (black, Hispanic or other).

In addition, the NLSY97 provides data on a number of other factors which may influence alcohol consumption. The NLSY97 includes a set of questions on schooling, academic achievement and aptitudes. These include a dichotomous variable equal to one for youths currently not in school. A variable measuring years of schooling completed was also defined. Also, a variable measuring the individual's math score on the Peabody Individual Achievement Test was defined. In addition, a set of variables which measure parental supervision were defined. These include a variable which measures how often the respondent eats dinner with their family. A review by the Council of Economic Advisors (2000) found this variable to be a significant predictor of alcohol use. Also, the respondents are asked to report the number of times during a typical week that they do something religious as a family. The response data ranges from zero to seven. Furthermore, a youth's ability to cope with stress and the difficulties of adolescence may affect their alcohol consumption. Youths that report that they can get emotional support from their parents may be less likely to use alcohol. An index of family relationship is provided in the NLSY97. This index takes on values from zero to 32 , with higher values indicating a closer relationship. In addition, a household size variable is defined. Also a dichotomous variable equal to one if the individual worked in the past year was defined. A dichotomous variable measuring the presence of

\footnotetext{
${ }^{6}$ The other category includes individuals who did not respond to the race question to minimize loss of data due to non-
} 
another individual during the interview was also included. Finally, a year dummy is included. Table 3 provides summary definitions and means for the variables which were used in the regressions from the NLSY97.

Advertising data, alcohol price data and cost of living data are appended to both the MTF and the NLSY97. Since 1996 and 1998 MTF data and 1997 and 1998 NLSY97 data are used in this study, the advertising data which was purchased includes the years 1996 to 1998. The advertising data come from Competitive Media Reporting (CMR). CMR collects advertising data in broadcast, outdoor and other media. The reliability of these data is widely recognized in the advertising industry. All of the data reported by CMR are independent estimates and do not use any information from alcohol producers. The data are collected by monitoring the media, from broadcast station reports and advertising wholesalers' reports. Only alcohol advertising data with local variation have been used in this study. Network television, syndicated television, cable network television and network radio all have no local variation and in a regression model these data would simply affect the intercept. Spot television, spot radio, outdoor and newspapers all have local variation and are reported by advertising market areas. Magazine advertising can also be included since national advertising expenditures and local circulation are available. Local magazine advertising is estimated by multiplying national advertising by the percent of total circulation in the local market. An advertising market area is known as a Designated Market Area (DMA) and is similar to a Metropolitan Statistical Area. The advertising data were appended to the individual records by DMA. This approach provides cross sectional variance in the advertising data, which is an important empirical issue in measuring the effect of advertising. A single media

response. Excluding observations with missing race information does not materially change the results. 
aggregated advertising variable is useful because it accounts for all media and media substitution while avoiding problems of colinearity between media.

The advertising variable which is appended to the individual data should approximate the exposure of an average youth to alcohol advertising. The local level alcohol advertising data that are available include: spot television expenditures, spot radio expenditures, outdoor expenditures, magazine expenditures and newspaper expenditures. National level advertising has no local variation and is not included. The construction of the advertising variable assumes a competitive market for advertising. Let:

$\mathrm{A}_{\mathrm{tv}}=\mathrm{a}$ spot $\mathrm{TV}$ advertising message, $\mathrm{A}_{\mathrm{i}}=$ an advertising message in other local media, $\mathrm{i}$, $\mathrm{P}_{\mathrm{tv}}=$ price of a TV advertising message, $\mathrm{P}_{\mathrm{i}}=$ price of an advertising message in other local media, $\mathrm{i}$ and $\mathrm{P}_{\mathrm{tv}}=\mathrm{q}_{\mathrm{i}} \mathrm{P}_{\mathrm{i}}$ where $\mathrm{q}_{\mathrm{i}}$ measures the impact of a TV advertisement relative to an advertisement in another local media.

The advertising variable is constructed by converting all expenditure data to TV equivalent messages. This conversion can be done by assuming that the price of a TV message relative to the price of a message in another media is equal to impact of the TV message relative to the impact of a message in another media. The price of TV advertising is calculated using data on number of seconds and advertising expenditures on spot TV. The price per second is calculated from these data by dividing expenditures by number of seconds which was done, by year, for each DMA. TV equivalent messages for media i are $A_{i} / q_{i}$. If A measures total TV equivalent messages, then $A=A_{t v}+\Sigma A_{i} / q_{i}$. Since $\mathrm{A}_{\mathrm{tv}}$ can be multiplied by $\mathrm{P}_{\mathrm{tv}} / \mathrm{P}_{\mathrm{tv}}$, and $1 / \mathrm{q}_{\mathrm{i}}$ replaced by $\mathrm{P}_{\mathrm{i}} / \mathrm{P}_{\mathrm{tv}}$, then $\mathrm{A}=\mathrm{A}_{\mathrm{tv}} \mathrm{P}_{\mathrm{tv}} / \mathrm{P}_{\mathrm{tv}}+\Sigma \mathrm{A}_{\mathrm{i}} \mathrm{P}_{\mathrm{i}} / \mathrm{P}_{\mathrm{tv}}$. Total TV equivalent messages are thus equal to the sum of advertising expenditures on the five local media, 
divided by the price of one second of spot TV advertising. Since the number of messages in a DMA increases with population size, the total message variable is divided by DMA population. ${ }^{7}$

An important aspect of advertising is that its effects linger over time. That is, advertising in one period will have a lingering, although an ever smaller effect, in subsequent periods. This could be modeled as a Koyck transformation with constant rate of decay. A stock of advertising is created since in each period new advertising is added to the depreciated advertising from prior periods. However, the rate of decay from one period to the next is unknown and remains an arguable issue. Research such as Boyd and Seldon (1990) finds that specific advertisements fully depreciate within a year. An advertisement for a specific product helps create a personality for that product but it also creates an expectancy about alcohol in general. Even if a specific advertisement completely decays in less than a year, the expectancy about alcohol may linger for a longer period. If the decay rate and structure were known, then a measure of stock could be calculated.

The dependent variables which are used in this paper are annual participation, monthly participation and binge participation. Annual advertising can be matched to annual participation, and annual advertising can be assumed to be a proxy for the stock of advertising when monthly participation data are used. ${ }^{8}$ The regression results are interpreted as an estimate of the marginal effect of an increase in annual advertising on annual, monthly alcohol participation and binge participation.

Since beer is the most widely used alcoholic beverage by underaged drinkers the price of beer is used in the demand functions. Data on the money price of beer was taken from the Inter-City

\footnotetext{
${ }^{7}$ According to the Center on Alcohol Marketing and Youth, youth exposure is in the same range as overall population exposure.

${ }^{8}$ The stock of advertising is equal to the current period advertising plus the discounted value of advertising from prior periods. Let advertising in each period be equal to an average value plus a positive or negative deviation from this average value. The sum of the discounted values of the deviations can be assumed to equal zero. The stock of
} 
Cost of Living Index, published quarterly by the American Chamber of Commerce Researchers Association (ACCRA). This data set includes prices for all the years and DMAs included in the data sets. The ACCRA data contain the price of standard brands of beer for the years included in the alcohol data sets.

The price of beer and income are adjusted for local cost of living and price changes over time. Data on the local cost of living were taken from the Inter-City Cost of Living Index, published quarterly by the American Chamber of Commerce Researchers Association (ACCRA). The ACCRA cost of living index is based on over sixty categories of consumer purchases and uses expenditure weights based on government survey data of expenditures of mid-management households. The ACCRA cost of living index has no time variation and is indexed to one for the average cost of living. Price changes over time were measured with the national CPI for all urban consumers reported in Business Conditions Digest (Bureau of Economic Analysis, USDC). The cost of living index used to adjust beer prices and income was computed by multiplying the ACCRA index by the national CPI.

\section{Results}

The first empirical issue is potential endogeneity between alcohol advertising and youth alcohol participation. One source of endogeneity reflects the direction of causality. Current period advertising could be a function of aggregate sales in the prior period for the overall population. However, in the models estimated in this study, the dependent variables are dichotomous indicators of youth alcohol participation, which may only be weakly correlated with consumption in the overall population. Furthermore, while reverse causality may run from past period sales to current period advertising, the models in this study estimate current period consumption as a function of current or past period advertising. Thus, a priori, this source of endogeneity does not appear likely. Another form of 
endogeneity may be due to unobserved factors, which are correlated with both youth alcohol participation and advertising. The extensive set of variables available in the NLSY97 and the individual fixed effects models should account for this unobserved heterogeneity.

Nevertheless, the potential for endogeneity does remain. The alcohol participation equations were tested with the Smith-Blundell and Wu-Hausman tests. ${ }^{9}$ This requires the specification of a reduced form advertising demand function. This advertising demand function includes all of the exogenous variables from the alcohol demand function and also the price of beer advertising on TV and the price of wine advertising on TV. ${ }^{10}$ Advertising price strongly affects the level of advertising, but has no direct effect on youth alcohol participation. Endogeneity was tested for annual, monthly and binge participation for the MTF full sample, and for monthly and binge participation for all specifications with the NLSY97 data. As expected, all nine tests rejected endogeneity and the alcohol participation models are estimated with single equation techniques.

Table 4 presents the results from the estimation of 15 alternative specifications of the alcohol demand equation with the MTF data. The table has three sections which follow the same pattern. Each section contains five probit regressions which use alternative sample populations. The first regression uses the full sample, the second and third limit the sample to whites and blacks, respectively, while the fourth and fifth limit the sample to males and females, respectively. Each section presents results for a different dependent variable.

The results for annual and monthly alcohol participation are presented in the first and second section of table 4. For annual participation, alcohol advertising is positive and significant in four out of

to the average value times the number of periods. Annual advertising is thus proportional to the stock of advertising.

${ }^{9}$ The Smith-Blundell test is a version of the Wu-Hausman test for exogeneity, applied to structural equations estimated as probit. This test, which is related to an auxiliary regression test for exogeneity, involves testing for the exclusion of the residual vector obtained from the first-stage regression. Under the null hypothesis, these residuals should have no explanatory power in the structural equation. See Smith and Blundell (1986).

${ }^{10}$ Spirits did not use TV advertising during this period. 
five regressions. For monthly participation, alcohol advertising is positive and significant in three regressions. Two of these insignificant coefficients are for blacks and one is for males. Alcohol price is negative and significant in all five annual participation regressions and negative and significant in three monthly regressions. The two insignificant coefficients are again in the black and male regressions. Income and age are positive and significant in all five regressions for both annual and monthly participation. The Hispanic variable is never significant in the annual participation regressions and negative and significant in two out of three monthly participation regressions. The other race variable is negative and significant in all regressions.

The results for binge participation in the past two weeks are presented in section 3 of table 4 and are similar to the other two alcohol use measures. Alcohol advertising is positive and significant in four out of five regressions while alcohol price is negative and significant in three regressions. Income is positive and significant in all five regressions and age is positive and significant in four regressions. The Hispanic variable is negative and significant only in the female regression. The other race variable is negative and significant in all three regressions indicating lower binge drinking.

The race specific regressions in table 4 allow for all the coefficients to vary between groups. A comparison of white and black regressions shows that the coefficients are generally lower for blacks. Also, the pseudo R-squares for blacks are about 0.03 while they are about 0.06 to 0.07 for whites. This indicates that the regression equation can explain more of the variance in participation for whites than for blacks. From the table of means, participation for whites is one and a half to two times higher than participation for blacks. These differences in simple means are mirrored by the negative and significant black variable in the regressions estimated with the full sample and the gender specific samples. The marginal effects suggest that being black reduces the probability of past year and monthly alcohol participation by about 18 percentage points. For binge participation, the marginal effect is about 14 
percentage points, similar to the difference of 0.13 suggested by the simple means. Overall, the results indicate that blacks participate less than whites and that their participation is less responsive to policy than the participation by whites.

A comparison of male and female regressions in table 4 shows that for annual participation price and advertising effects are larger for females but otherwise the coefficients are about the same. For monthly participation and binge participation, price and advertising effects are significant for females but not for males. However, the R-squares for males are larger than those for females. The table of means shows that annual and monthly participation for males and females are about equal. However, the male variable in the regressions estimated with the full sample and the race specific samples is negative and significant for annual participation, and significantly positive for monthly and binge participation. While the difference is not large, this indicates that when other factors are held constant, male annual participation is somewhat less than that for females. When other factors are held constant, males tend to have higher monthly participation than females. However, the male variable in the white regression is not significant. Binge participation for males is also somewhat higher than for females. This is also reflected in the male variable in the regressions estimated with the full sample and the race specific samples which is positive and significant. Overall, the results indicate that males participate more than females and that male participation is explained more by demographics than public policy.

Table 5 presents the results from the estimation of six alcohol demand equations with the NLSY97 data. Specifications 1 and 2 are estimated with probit. Specification 1 uses a limited set of independent variables and is comparable to the MTF specification. Specification 2 uses an extended set of independent variables, which are included to control for individual heterogeneity not controlled in the limited specifications. Specification 3 limits the independent variables but includes a full set of 
individual dummies and one time dummy variable. These dummy variable specifications control for all individual specific time invariant unobservable factors and also controls for individual invariant time specific factors. In these specifications, an included independent variable can only explain changes in alcohol participation that occur for individuals across time. For this reason the included independent variables are limited to advertising, price and income.

In table 5, alcohol advertising is positive and significant in all six regressions. The addition of variables which control for a greater degree of individual heterogeneity results in larger advertising coefficients. Alcohol price is negative and significant in four regressions and not significant in the two fixed effects models. A regression of alcohol price on the individual and time dummies produced an Rsquare of 0.98 , which indicates that there is very little variation in alcohol prices across individuals over time. For this reason the alcohol price variable has very little independent variance which might correlate with participation and is insignificant. Income is positive and significant in four of the six regressions. The F-tests on the individual dummy variables in both the fixed effects models are significant indicating that these dummies have an effect on participation. The significance of the dummies indicates that controlling for unobserved heterogeneity across individuals is important.

Specifications 1 and 2 include additional independent variables. Income, age, Hispanic and other race are also included in the MTF. The results for these variables from both the MTF and NLSY97 are very similar. Income is positive and significant in four out of six regressions. Age is positive and significant in all four regressions. The Hispanic variable is insignificant but the other race variable is negative and significant in three out of four regressions. Specification 2 includes a number of added variables which may influence alcohol consumption. These include a dichotomous variable equal to one for youths currently not in school which is insignificant in both regressions. The work variable is positive and significant in both regressions. The years of schooling variable is 
also positive and significant in both regressions. The measure of math achievement is negative and significant in both regressions. The family variables (family dinner, family religiosity, family relationship) are all negative and significant in both regressions. And finally, the variable measuring the presence of another individual during the survey interview is negative and significant in both regressions. This variable may account for youths who may have understated their true alcohol use due to the presence of a parent or guardian during the interview.

Table 6 presents the participation-advertising elasticities. From the MTF, the full sample annual participation advertising elasticity is about 0.02 . The past month participation-advertising elasticity is about the same magnitude while the elasticity for binge participation is about half this size. The elasticity estimates with the subsamples, where significant, follow this pattern. This regularity in the results can be used to make a best guess for the insignificant black and male elasticities. The pattern shows small differences by gender and race that have no substantive importance. From the NLSY97, past month elasticity is about 0.03 in the limited specification. The elasticities estimated with the extended specification and the fixed effects specifications are between 0.06 and 0.11 . The binge elasticity is about 0.04 in the limited specification and between 0.11 and 0.18 in the extended and fixed effects specifications.

The elasticities presented in table 6 show the direction of bias due to heterogeneity. Table 6 presents alternative estimates of the advertising-past month participation elasticity from the MTF and from the NLSY97. The estimated elasticities are very close in absolute terms. The same pattern is evident in the binge drinking elasticities. The NLSY97 extended specification controls for more heterogeneity than the limited specification and the fixed effects regressions control for all time invariant individual heterogeneity. Table 6 shows that the elasticities increase as more controls for heterogeneity are added. This suggests that heterogeneity bias results in an understatement of the effect 
of advertising. The best guess elasticities are calculated from the NLSY97 extended and fixed effects specifications. Averaging the NLSY97 elasticities for past month participation from the extended and fixed effects models results in a value of about 0.08 , and for binge participation results in a value of about 0.14 .

Table 6 also presents the participation price elasticities. From the MTF, the full sample past year participation price elasticity is about -0.13 . For past month, the magnitude is about the same and for binge participation it is about one-third this size. The pattern shows small differences by race and gender with lower values for blacks and higher values for females. From the NLSY97, past month price elasticity is about -0.19 in the limited specification. The elasticity estimated with the extended specification is higher at about -0.28 . The binge elasticity is about -0.20 in the limited specification and about -0.51 in the extended specification. This again suggests that controlling for individual heterogeneity increases the elasticities and that the estimates from the MTF may understate the true effect. The NLSY97 price elasticities for the extended specification may be the best since heterogeneity is controlled to the best degree possible. These values are -0.28 for past month alcoholprice participation, and -0.51 for binge-price participation.

\section{Conclusions}

Both the MTF and NLSY97 results contribute to the analyses and provide an important comparison. The large size of the MTF data set makes it possible to estimate regressions with race and gender specific subsamples. The panel nature of the NLSY97 makes it possible to estimate individual fixed effects models. In addition very similar models can be estimated with both data sets. Since the data sets are independent, the basically similar findings increase the confidence in all the results. 
The results from the MTF and the NLSY97 generally show that alcohol advertising has a positive effect on annual alcohol participation, monthly participation and binge participation. Alcohol price generally has a negative effect on these participation measures. Overall, the results indicate that blacks participate less than whites and their participation cannot be explained with the included variables as well as it can for whites. A comparison of male and female regressions shows that price and advertising effects are generally larger for females, but otherwise the coefficients are about the same. An important finding with the NLSY97 is that controlling for individual heterogeneity increases the effects of advertising. This suggests that the results from the MTF may understate the true effects. However, the relative black-white differences and male-female differences from the MTF are most likely unaffected by the lack of control for heterogeneity.

The elasticity of advertising with respect to past month participation was estimated at about 0.08 and with respect to binge participation at about 0.14 . Since only local advertising is included, the actual range of potential reduction is around 300 percent. Local advertising is only about one-third of total advertising expenditures. Thus the complete elimination of alcohol advertising would amount to a 300 percent reduction. This suggests that the compete elimination of alcohol advertising could reduce adolescent monthly alcohol participation by about 24 percent and binge participation by about 42 percent.

The size of the price increases needed to result in a commensurate reduction can be estimated with price elasticities. This provides a comparison of the effectiveness of advertising reductions with tax increases as alternative policies. The price elasticities for past month participation was estimated at about -0.28 and the binge participation elasticity at about -0.51 . This suggests that a 100 percent increase in alcohol prices would be needed to reduce adolescent monthly alcohol participation by 28 percent, and this would reduce binge participation by 51 percent. For 
monthly participation, the effect of a complete elimination of alcohol advertising would be similar to a 100 percent increase in alcohol prices. For binge participation, the effect of a complete elimination of advertising would be equivalent to about an 80 percent increase in price. As a result, both advertising and price policies are shown to have the potential to substantially reduce adolescent alcohol participation. 


\section{$\underline{\text { References }}$}

Ackoff, R. and J. Emshoff, “Advertising Research at Anheuser-Busch, Inc. (1963-68),” Sloan Management Review, Winter, p. 1-15, 1975.

Advertising Age, Sales per Ad Dollar by Most Advertised Segment, www.adage.com, 1999.

American Chamber of Commerce Researchers Association, ACCRA Cost of Living Index, Alexandria, Virginia, 1997-1999.

Becker, G. and Murphy, K., "A Simple Theory of Advertising as a Good or Bad”, Quarterly Journal of Economics, 108, no. 4, 1993.

Blake, D. and A. Nied, "The Demand for Alcohol in the United Kingdom", Applied Economics, 29, 1655-1672, 1997.

Bourgeois, J. and J. Barnes, "Does Advertising Increase Alcohol Consumption?", Journal of Advertising Research 19, 1979, 19-29.

Boyd, R. and B. Seldon, “The Fleeting Effect of Advertising”, Economic Letters, 34, 1990.

Breed, W., Wallack, L., and Grube, J. "Alcohol Advertising in College Newspapers: A 7-Year Follow-up", College Health, vol. 38, May, 1990.

Bureau of Economic Analysis, Business Conditions Digest, United States Department of Commerce, 1996-1999.

Calfee, J. and C. Scheraga, "The Influence of Advertising on Alcohol Consumption: A Literature Review and An Econometric Analysis of Four European Nations," International Journal of Advertising, vol. 13, no. 4, 1994. p. 287-310.

Center for Media Education, Alcohol Advertising Targeted at Youth on the Internet: An Update, http://tap.epn.org, 1998.

Center on Alcohol Marketing and Youth. Overexposed, Georgetown University, September 24, 2002.

Center on Alcohol Marketing and Youth. Drops in the bucket, Georgetown University, February 3, 2003.

Center on Alcohol Marketing and Youth. Radio Daze, Georgetown University, April 3, 2003.

Comanor, W., and Wilson, T., Advertising and Market Power, Cambridge: Harvard University Press, 1974.

Competitive Media Reporting, LNA/Media Watch Multi-Media Service, CMR, New York, 2001. 
Council of Economic Advisors, Teens and Their Parents in the $21^{\text {st }}$ Century, http://clinton4.nara.gov/media/pdf/CEAreport.pdf, 2000.

Duffy, M., "The Demand for Alcoholic Drink in the United Kingdom, 1963-78", Applied Economics, $15,1983,125-140$.

Duffy, M., "Advertising and the Inter-product Distribution of Demand", European Economic Review, 31, 1987, 1051-1070.

Duffy, M. "Advertising in Demand Systems: Testing a Galbraithian Hypothesis", Applied Economics, 23, 1991, 485-496.

Duffy, M., "Advertising in Demand Systems for Alcoholic Drinks and Tobacco: A Comparative Study," Journal of Policy Modeling, vol. 17 no. 6, p. 557-577, 1995.

Duffy, M. “Advertising in Consumer Allocation Models: Choice if Functional Form”, Applied Economics, 33, 437-456, 2001.

Federal Trade Commission, Self-regulation in the Alcohol Industry, A Review of Industry Efforts to Avoid Promoting Alcohol to Underage Consumers, www.ftc.gov, 1999.

Fisher, J. Advertising, Alcohol Consumption, and Abuse, A Worldwide Survey, Greenwood Press: Westport, 1993.

Fisher, J. and Cook, P., Advertising, Alcohol Consumption and Mortality: An Empirical Investigation, Westport CT, Greenwood Press, 1995

Franke, G. and G. Wilcox, "Alcoholic Beverage Advertising and Consumption in the United States, 1964-1984", Journal of Advertising, 16, 1987, 22-30.

Gius, M. P., "Using panel data to determine the effect of advertising on brand-level distilled spirits sales" Journal of Studies on Alcohol, 57, 73-76, 1996.

Goel, R., and M. Morey, "The Interdependence of Cigarette and Liquor Demand," Southern Economic Journal, vol. 62, no. 2, p. 441-459, 1995.

Grabowski, H. "The Effects of Advertising on the Interindustry Distribution of Demand", Explorations in Economic Research, 3, 21-75 1976.

Grube, J. "Alcohol Portrayals and Alcohol Advertising on Television: Content and Effects on Children and Adolescents," Alcohol Health and Research World, vol. 17, no. 1, p. 61-66, 1993.

Grube, J. and L. Wallack, "Television beer Advertising and Drinking Knowledge, Beliefs, and Intentions among Schoolchildren", American Journal of Public Health, vol. 84, no. 2, Feb. 1994. 
Grube, J. "Television Alcohol Portrayals, Alcohol Advertising, and Alcohol Expectancies Among Children and Adolescents", Effects of the Mass Media on the Use and Abuse of Alcohol, Martin, S.E., and Mail, P., eds. Bethesda, MD: National Institute on Alcohol Abuse and Alcoholism, 1995, $105-121$.

Johnson, L., "Alternative Econometric Estimates of the Effects of Advertising on the Demand for Alcoholic Beverages in the United Kingdom", International Journal of Advertising, 4, 1985, 19-25.

Johnston, L. P. O'Malley, and J. Bachman, National Survey Results on Drug Use From Monitoring the Future Study, 1975-1994: Volume 1, Secondary School Students, Rockville MD. NIDA, 2002.

Kelly, K. and Edwards, R., "Image Advertisements for Alcohol Products: Is their Appeal Associated with Adolescent Intention to Drink?”, Adolescence, 33, 47-59, 1998.

Larivière, E., Larue, B. and Chalfant, J., "Modeling the Demand for Alcoholic Beverages and Advertising Specifications", Agricultural Economics, 22, 147-162, 2000.

Lee, B. and V. Tremblay, "Advertising and the US Market Demand for Beer", Applied Economics, 24, 1992, 69-76.

Maddala G. Limited Dependent and Qualitative Variables in Economics, Cambridge, England: Cambridge University Press, 1983.

Makowsky, C., and P. Whitehead, “Advertising and Alcohol Sales: A Legal Impact Study,” Journal of Studies on Alcohol, vol. 52, no. 6, 1991. p. 555-566.

Martin, S. et al. "Alcohol Advertising and Youth", Alcohol Clinical and Experimental Research, 26(6), 900-906, 2002.

McGuiness, T. "An Econometric Analysis of Total Demand for Alcoholic Beverages in the U.K. 19561975", Journal of Industrial Economics, 29, 85-105, 1980.

McGuiness, T. "The Demand for Beer, Spirits and Wine in the UK, 1956-1979", in Grant, Plant and Williams, eds. Economics and Alcohol Gardner Press, Inc. New York. 1983, 238-242.

Nelson J. Broadcast Advertising and US Demand for Alcoholic Beverages", $\underline{\text { Southern Economic }}$ Journal 65(4) 774-790, 1999.

Nelson J. P. and Young, D. J. (2001). "Do advertising bans work? An international comparison", International Journal of Advertising, 20, 273-296.

Nelson J. and J. Moran, "Advertising and US Alcoholic Beverage Demand: System-Wide Estimates," Applied Economics, vol. 27, 1995. p. 1225-1236.

Ogborne, A., and Smart, R., Will Restrictions on Alcohol Advertising Reduce Alcohol Consumption?," British Journal of Addiction, 75, 293-296 1980. 
Ornstein, S. and Hanssens, D., "Alcohol Control Laws and the Consumption of Distilled Spirits and Beer", Journal of Consumer Research, 12, 200-213, 1985.

Parker, B. "Exploring Life Themes and Myths in Alcohol Advertisements through a MeaningBased Model of Advertising Experiences, Journal of Advertising, vol. xxvii no. 1, Spring, 1998.

Rao, R. and P. Miller, “Advertising/Sales Response Functions”, Journal of Advertising Research, 15:7-15, 1975.

Robert Wood Johnson Foundation, Advances, no.1, 1999.

Saffer, H., "Alcohol Advertising Bans and Alcohol Abuse: An International Perspective," Journal of Health Economics, 10., 65-79, 1991.

Saffer, H., "Alcohol Advertising and Highway Fatalities," Review of Economics and Statistics, 79, 431-442, 1997.

Saffer, H., and Dave, D., "Alcohol Consumption and Alcohol Advertising Bans", Applied Economics, 34, 2002, 1325-1334.

Schmalensee, R. The Economics of Advertising, Amsterdam: North-Holland, 1972.

Selvanathan, E., "Advertising and Alcohol Demand in the UK: Further Results", International Journal of Advertising, 8, 1989, 181-188.

Smart, R. and Cutler R., "The Alcohol Advertising Ban in British Columbia: Problems and Effects on Beverage Consumption," British Journal of Addiction, 71, 13-21 1976.

Smith, R. J., and Blundell, R. W. “An Exogeneity Test for a Simultaneous Equation Tobit Model with an Application to Labor Supply.” Econometrica, vol. 54, no. 3, 1986, 679-685.

Walsh B., "The Demand for Alcohol in the UK: A Comment", The Journal of Industrial Economics, vol. 30, no. 4, June 1982.

Young, D., "Alcohol Advertising Bans and Alcohol Abuse: Comment", Journal of Health Economics, 12, 213-228, 1993. 

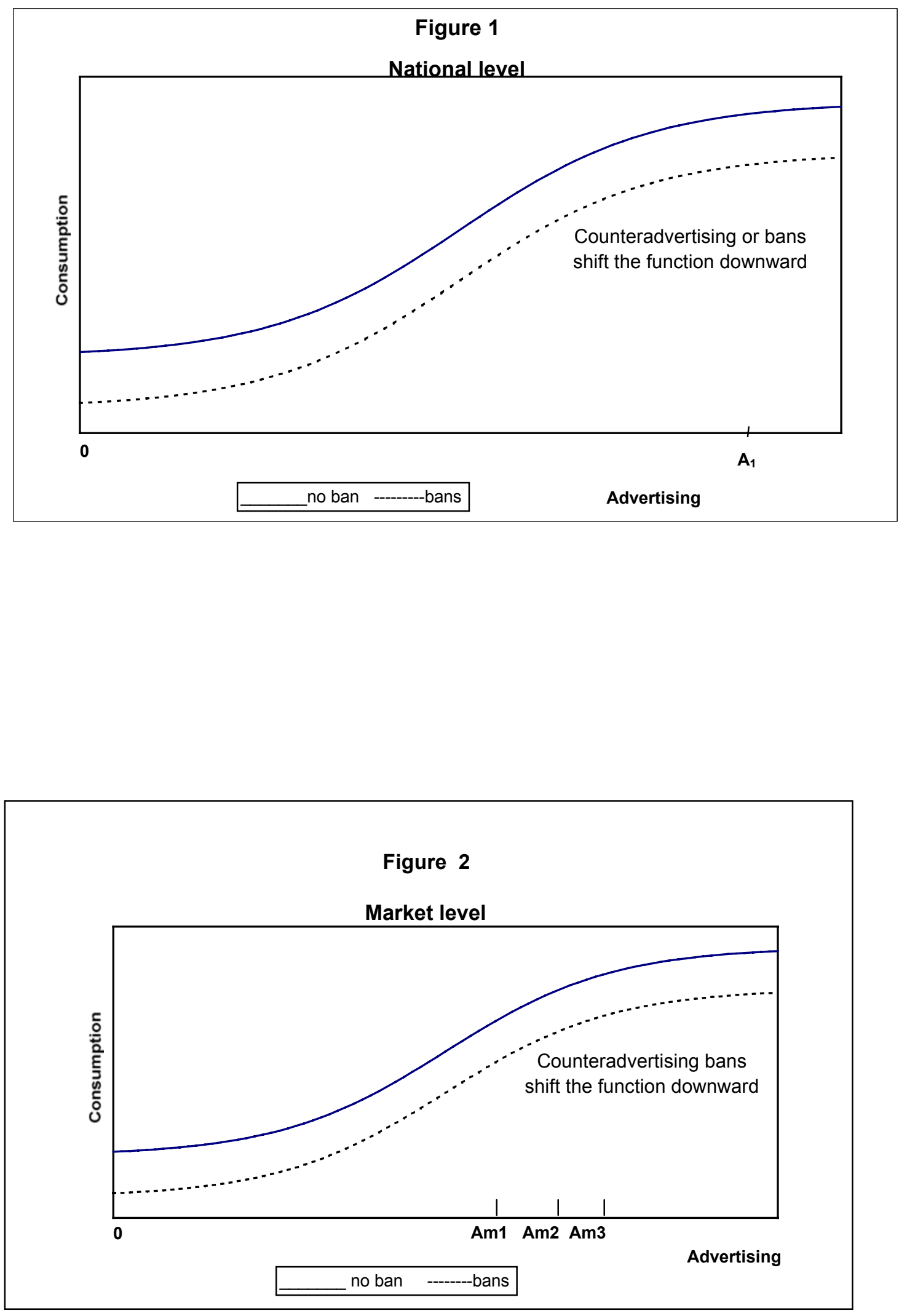
Table 1

Prior Empirical Studies

\begin{tabular}{|c|c|c|}
\hline STUDY & DATA & CONCLUSION \\
\hline \multicolumn{3}{|l|}{ TIME SERIES STUDIES* } \\
\hline Blake and Nied (1997) & UK 1952-1991 & Small positive effect of advertising \\
\hline Bourgeois and Barnes (1979) & Canada 1951-1974 & No effect of advertising \\
\hline Calfee and Scheraga (1994) & $\begin{array}{l}\text { France Germany, } \\
\text { Netherlands Sweden }\end{array}$ & No effect of advertising \\
\hline Duffy (1987) & UK 1963-1983 & No effect of advertising \\
\hline Duffy (1991) & UK1963-1985 quarterly & No effect of advertising \\
\hline Duffy (1995) & UK1963-1988 quarterly & No effect of advertising \\
\hline Duffy (2001) & UK 1964-1996 quarterly & No effect of advertising \\
\hline Franke and Wilcox (1987) & US 1964-1984 quarterly & $\begin{array}{l}\text { Small positive effect of beer and } \\
\text { wine advertising }\end{array}$ \\
\hline Grabowski (1976) & US 1956-1972 & No effect of advertising \\
\hline Lee and Trembley (1992) & US 1953- 1983 & No effect of advertising \\
\hline McGuiness (1980) & UK 1956-1975 & $\begin{array}{l}\text { Small positive effect of spirits } \\
\text { advertising }\end{array}$ \\
\hline McGuiness (1983) & UK 1956-1979 & $\begin{array}{l}\text { Small positive effect of beer } \\
\text { advertising }\end{array}$ \\
\hline Nelson (1999) & US quarterly & No effect of advertising \\
\hline Nelson and Moran (1995) & US 1964-1990 & No effect of advertising \\
\hline Selvanathan (1989) & UK 1955-1975 & $\begin{array}{l}\text { Small positive effect of beer } \\
\text { advertising }\end{array}$ \\
\hline \multicolumn{3}{|l|}{$\begin{array}{c}\text { CROSS-SECTIONAL } \\
\text { STUDIES }\end{array}$} \\
\hline Goel and Morey (1995) & US 1959-1982 & Positive effect of advertising \\
\hline Saffer (1997) & US 1986-1989 quarterly & Positive effect of advertising \\
\hline \multicolumn{3}{|l|}{ BAN STUDIES } \\
\hline \multicolumn{3}{|l|}{ Interrupted Time Series } \\
\hline $\begin{array}{l}\text { Makowsky and Whitehead } \\
\text { (1991) }\end{array}$ & Saskatchewan & No effect of advertising \\
\hline Ogborne and Smart (1980) & Manitoba & No effect of advertising \\
\hline Smart and Cutler (1976), & British Columbia, & No effect of advertising \\
\hline \multicolumn{3}{|l|}{ Multivariate } \\
\hline Ornstein and Hanssens (1985) & US $1974-1978$ & Positive effect of price advertising \\
\hline Saffer (1991) & OECD $1970-1990$ & Negative effect of bans \\
\hline Young (1993) & OECD $1970-1990$ & Mixed \\
\hline Nelson and Young (2001) & OECD $1970-1990$ & Positive effect of bans \\
\hline Saffer and Dave (2002) & OECD 1970-1995 & Negative effect of bans \\
\hline
\end{tabular}


Table 2

Weighted Means MTF

\begin{tabular}{|c|c|c|c|c|c|c|}
\hline Variable & Definition & $\begin{array}{c}\text { Full } \\
\text { Sample }\end{array}$ & Whites & Blacks & Males & Females \\
\hline $\begin{array}{l}\text { Past Year Alcohol } \\
\text { Participation }\end{array}$ & $\begin{array}{l}\text { Dichotomous variable for whether respondent } \\
\text { drank more than a few sips of alcohol during } \\
\text { the past year }\end{array}$ & 0.5957 & 0.6278 & 0.4788 & 0.5977 & 0.5938 \\
\hline $\begin{array}{l}\text { Past Month } \\
\text { Alcohol } \\
\text { Participation }\end{array}$ & $\begin{array}{l}\text { Dichotomous variable for whether respondent } \\
\text { drank more than a few sips of alcohol during } \\
\text { the past } 30 \text { days }\end{array}$ & 0.3679 & 0.4041 & 0.2359 & 0.3850 & 0.3521 \\
\hline Binge Participation & $\begin{array}{l}\text { Dichotomous variable for whether the } \\
\text { respondent had five or more drinks in a row } \\
\text { over the last two weeks }\end{array}$ & 0.2183 & 0.2433 & 0.1127 & 0.2481 & 0.1909 \\
\hline Beer Price & $\begin{array}{l}\text { Price of six } 12 \text { ounce containers of beer in the } \\
\text { respondent's city of residence, adjusted by the } \\
\text { inter-city cost of living index and the annual } \\
\text { consumer price index }\end{array}$ & 2.4791 & 2.5443 & 2.4339 & 2.4902 & 2.4688 \\
\hline Income & $\begin{array}{l}\text { Average weekly income from all sources, in } \\
\text { dollars, adjusted by the inter-city cost of living } \\
\text { index and the annual consumer price index }\end{array}$ & 27.6304 & 27.3961 & 35.2862 & 31.1833 & 24.3466 \\
\hline $\begin{array}{l}\text { Alcohol } \\
\text { Advertising }\end{array}$ & $\begin{array}{l}\text { Per capita equivalent units of beer and wine } \\
\text { advertising on spot television, spot radio, } \\
\text { outdoors, newspapers, and magazines and } \\
\text { liquor advertising outdoors, in newspapers, } \\
\text { and magazines in the respondent's city of } \\
\text { residence, in 1000's }\end{array}$ & 0.00008 & 0.00008 & 0.00007 & 0.00008 & 0.00008 \\
\hline $\begin{array}{l}\text { Beer Advertising } \\
\text { Price }\end{array}$ & $\begin{array}{l}\text { Spot television beer advertising price per } \\
\text { second based on } 30 \text {-seconds ads adjusted by } \\
\text { the inter-city cost of living index and the } \\
\text { annual consumer price index, in dollars }\end{array}$ & 21.7077 & 19.7053 & 23.3075 & 21.5359 & 21.8665 \\
\hline $\begin{array}{l}\text { Wine Advertising } \\
\text { Price }\end{array}$ & $\begin{array}{l}\text { Spot television wine advertising price per } \\
\text { second based on } 30 \text {-seconds ads adjusted by } \\
\text { the inter-city cost of living index and the } \\
\text { annual consumer price index, in dollars }\end{array}$ & 26.3487 & 23.5444 & 31.5638 & 25.9771 & 26.6889 \\
\hline Age & Respondent's age & 15.3718 & 15.4499 & 15.3168 & 15.4006 & 15.3452 \\
\hline Mal & $\begin{array}{l}\text { Dichotomous variable for whether the } \\
\text { respondent is male }\end{array}$ & 0.4803 & 0.4827 & 0.4528 & 1.0000 & 0.0000 \\
\hline Black & $\begin{array}{l}\text { Dichotomous variable for whether the } \\
\text { respondent is black }\end{array}$ & 0.1110 & 0.0000 & 1.0000 & 0.1046 & 0.1168 \\
\hline Hispanic & $\begin{array}{l}\text { Dichotomous variable for whether the } \\
\text { respondent is Hispanic }\end{array}$ & 0.1067 & 0.0000 & 0.0000 & 0.1070 & 0.1064 \\
\hline Other Race & $\begin{array}{l}\text { Dichotomous variable for whether the } \\
\text { respondent is any race other than white, black, } \\
\text { or Hispanic }\end{array}$ & 0.1379 & 0.0000 & 0.0000 & 0.1408 & 0.1352 \\
\hline Year 1998 & Dichotomous variable for 1998 & 0.4962 & 0.4856 & 0.5410 & 0.4926 & 0.4995 \\
\hline \multicolumn{2}{|c|}{ Number of Observations } & 63,369 & 40,410 & 7,186 & 30,114 & 33,255 \\
\hline
\end{tabular}

Notes: Number of observations listed represents the maximum number. For some variables, the sample size is slightly less due to missing information. 
Table 3

Weighted Means NLSY 97

\begin{tabular}{|c|c|c|}
\hline Variable & Definition & \\
\hline $\begin{array}{l}\text { Past Month Alcohol } \\
\text { Participation }\end{array}$ & $\begin{array}{l}\text { Dichotomous variable for whether respondent drank more } \\
\text { than a few sips of alcohol during the past } 30 \text { days }\end{array}$ & 0.2776 \\
\hline Binge Participation & $\begin{array}{l}\text { Dichotomous variable for whether the respondent had five or } \\
\text { more drinks in a row during the past } 30 \text { days }\end{array}$ & 0.1384 \\
\hline Beer Price & $\begin{array}{l}\text { Price of six } 12 \text { ounce containers of beer in the respondent's } \\
\text { city of residence, adjusted by the inter-city cost of living } \\
\text { index and the annual consumer price index }\end{array}$ & 2.4663 \\
\hline Income & $\begin{array}{l}\text { Total income from all sources in the past year, in dollars, } \\
\text { adjusted by the inter-city cost of living index and the annual } \\
\text { consumer price index }\end{array}$ & 412.1189 \\
\hline Alcohol Advertising & $\begin{array}{l}\text { Per capita equivalent units of beer and wine advertising on } \\
\text { spot television, spot radio, outdoors, newspapers, and } \\
\text { magazines and liquor advertising outdoors, in newspapers, } \\
\text { and magazines in the respondent's city of residence, in 1000's }\end{array}$ & 0.00008 \\
\hline Beer Advertising Price & $\begin{array}{l}\text { Spot television beer advertising price per second based on 30- } \\
\text { seconds ads adjusted by the inter-city cost of living index and } \\
\text { the annual consumer price index, in dollars }\end{array}$ & 23.9388 \\
\hline Wine Advertising Price & $\begin{array}{l}\text { Spot television wine advertising price per second based on } \\
30 \text {-seconds ads adjusted by the inter-city cost of living index } \\
\text { and the annual consumer price index, in dollars }\end{array}$ & 21.3526 \\
\hline Age & Respondent's age & 15.1615 \\
\hline Male & Dichotomous variable for whether the respondent is male & 0.5128 \\
\hline Black & Dichotomous variable for whether the respondent is black & 0.1648 \\
\hline Hispanic & Dichotomous variable for whether the respondent is Hispanic & 0.1291 \\
\hline Other Race & $\begin{array}{l}\text { Dichotomous variable for whether the respondent is any race } \\
\text { other than white, black, or Hispanic }\end{array}$ & 0.1280 \\
\hline High School Dropout & $\begin{array}{l}\text { Dichotomous variable for whether the respondent is not } \\
\text { enrolled in school and has not completed high school }\end{array}$ & 0.0488 \\
\hline Grade & Highest grade completed as of interview date & 8.5238 \\
\hline Work & $\begin{array}{l}\text { Dichotomous variable for whether the respondent received } \\
\text { any income from a job during the past year }\end{array}$ & 0.5173 \\
\hline Math Percentile Score & $\begin{array}{l}\text { Percentile score on math assessment in the Peabody } \\
\text { Individual Achievement Test }\end{array}$ & 51.1316 \\
\hline Both Parents & $\begin{array}{l}\text { Dichotomous variable for whether the respondent lives with } \\
\text { both parents, at least one of whom is a biological parent }\end{array}$ & 0.6635 \\
\hline Household Size & Number of members living in household & 4.3966 \\
\hline Family Dinner & $\begin{array}{l}\text { Number of days respondent eats dinner with family during a } \\
\text { typical week }\end{array}$ & 4.9182 \\
\hline Family Religiosity & $\begin{array}{l}\text { Number of days family does something religious during a } \\
\text { typical week }\end{array}$ & 1.3558 \\
\hline Family Relationship & Index of respondent's relationship with parents & 24.6114 \\
\hline Present During Interview & $\begin{array}{l}\text { Dichotomous variable for whether someone else was present } \\
\text { during respondent's interview }\end{array}$ & 0.2788 \\
\hline Year 1998 & Dichotomous variable for 1998 & 0.4982 \\
\hline \multicolumn{2}{|l|}{ Number of Observations } & 12,234 \\
\hline
\end{tabular}

Notes: Number of observations listed represents the maximum number. For some variables, the sample size is slightly less due to missing information. 





Table 5

NLSY97

\begin{tabular}{|c|c|c|c|c|c|c|}
\hline \multirow{3}{*}{ Variables } & \multicolumn{3}{|c|}{ Monthly Alcohol Participation } & \multicolumn{3}{|c|}{ Monthly Binge Participation } \\
\hline & 1 & 2 & 3 & 1 & 2 & 3 \\
\hline & Probit & Probit & $\begin{array}{c}\text { Fixed } \\
\text { Effects }\end{array}$ & Probit & Probit & $\begin{array}{l}\text { Fixed } \\
\text { Effects }\end{array}$ \\
\hline Beer Price & $\begin{array}{c}-0.0202 \\
(-2.27) \\
\end{array}$ & $\begin{array}{c}-0.0208 \\
(-1.67)\end{array}$ & $\begin{array}{l}0.0332 \\
(0.70) \\
\end{array}$ & $\begin{array}{r}-0.0100 \\
(-1.64) \\
\end{array}$ & $\begin{array}{r}-0.0145 \\
(-2.12) \\
\end{array}$ & $\begin{array}{c}0.0269 \\
(0.75) \\
\end{array}$ \\
\hline Alcohol Advertising & $\begin{array}{c}95.5219 \\
(2.11)\end{array}$ & $\begin{array}{c}137.1607 \\
(2.10)\end{array}$ & $\begin{array}{c}376.4269 \\
(2.75)\end{array}$ & $\begin{array}{c}57.3231 \\
(1.89)\end{array}$ & $\begin{array}{c}96.9340 \\
(2.97)\end{array}$ & $\begin{array}{c}314.8700 \\
(3.04)\end{array}$ \\
\hline Income & $\begin{array}{c}0.00002 \\
(4.56)\end{array}$ & $\begin{array}{c}0.00002 \\
(2.07)\end{array}$ & $\begin{array}{c}0.00001 \\
(1.40)\end{array}$ & $\begin{array}{c}0.00001 \\
(3.75)\end{array}$ & $\begin{array}{c}0.00001 \\
(1.51)\end{array}$ & $\begin{array}{c}0.00001 \\
(1.76)\end{array}$ \\
\hline Age & $\begin{array}{l}0.0640 \\
(21.51)\end{array}$ & $\begin{array}{l}0.0302 \\
(3.28)\end{array}$ & - & $\begin{array}{l}0.0396 \\
(18.83)\end{array}$ & $\begin{array}{c}0.0093 \\
(1.81)\end{array}$ & - \\
\hline Male & $\begin{array}{l}0.0047 \\
(0.58) \\
\end{array}$ & $\begin{array}{l}0.0081 \\
(0.73) \\
\end{array}$ & - & $\begin{array}{l}0.0223 \\
(3.97) \\
\end{array}$ & $\begin{array}{l}0.0082 \\
(1.36)\end{array}$ & - \\
\hline Black & $\begin{array}{l}-0.1245 \\
(-13.40) \\
\end{array}$ & $\begin{array}{c}-0.0715 \\
(-4.88) \\
\end{array}$ & - & $\begin{array}{l}-0.0785 \\
(-12.19) \\
\end{array}$ & $\begin{array}{r}-0.0433 \\
(-5.69) \\
\end{array}$ & - \\
\hline Hispanic & $\begin{array}{c}-0.0137 \\
(-1.16)\end{array}$ & $\begin{array}{l}0.0217 \\
(1.30)\end{array}$ & - & $\begin{array}{c}-0.0019 \\
(-0.24)\end{array}$ & $\begin{array}{c}-0.0039 \\
(-0.46)\end{array}$ & - \\
\hline Other Race & $\begin{array}{l}-0.0486 \\
(-3.80)\end{array}$ & $\begin{array}{c}-0.0404 \\
(-2.45)\end{array}$ & - & $\begin{array}{l}-0.0188 \\
(-2.18)\end{array}$ & $\begin{array}{c}-0.0059 \\
(-0.65)\end{array}$ & - \\
\hline High School Dropout & - & $\begin{array}{l}-0.0119 \\
(-0.33)\end{array}$ & - & - & $\begin{array}{c}0.0099 \\
(0.51)\end{array}$ & - \\
\hline Grade & - & $\begin{array}{l}0.0248 \\
(2.99)\end{array}$ & - & - & $\begin{array}{l}0.0145 \\
(3.15) \\
\end{array}$ & - \\
\hline Work & - & $\begin{array}{l}0.0250 \\
(2.13)\end{array}$ & - & - & $\begin{array}{l}0.0175 \\
(2.69)\end{array}$ & - \\
\hline Math Percentile Score & - & $\begin{array}{l}-0.0003 \\
(-1.68) \\
\end{array}$ & - & - & $\begin{array}{c}-0.0004 \\
(-4.48) \\
\end{array}$ & - \\
\hline Household Size & - & $\begin{array}{c}-0.0081 \\
(-1.89)\end{array}$ & - & - & $\begin{array}{r}-0.0033 \\
(-1.38)\end{array}$ & - \\
\hline Family Dinner & - & $\begin{array}{l}-0.0083 \\
(-3.32)\end{array}$ & - & - & $\begin{array}{l}-0.0053 \\
(-3.95)\end{array}$ & - \\
\hline Family Religiosity & - & $\begin{array}{l}-0.0071 \\
(-2.26)\end{array}$ & - & - & $\begin{array}{r}-0.0047 \\
(-2.48)\end{array}$ & - \\
\hline Family Relationship & - & $\begin{array}{l}-0.0122 \\
(-10.16) \\
\end{array}$ & - & - & $\begin{array}{l}-0.0045 \\
(-7.05)\end{array}$ & - \\
\hline $\begin{array}{l}\text { Present During } \\
\text { Interview }\end{array}$ & - & $\begin{array}{l}-0.0192 \\
(-1.61) \\
\end{array}$ & - & - & $\begin{array}{l}-0.0136 \\
(-2.09)\end{array}$ & - \\
\hline Year 1998 & $\begin{array}{l}0.0283 \\
(3.12)\end{array}$ & $\begin{array}{l}0.0419 \\
(2.91)\end{array}$ & $\begin{array}{l}0.1354 \\
(18.86)\end{array}$ & $\begin{array}{l}-0.0083 \\
(-1.31)\end{array}$ & $\begin{array}{r}-0.0066 \\
(-0.83)\end{array}$ & $\begin{array}{l}0.0615 \\
(11.32\end{array}$ \\
\hline R-square & 0.083 & 0.121 & 0.354 & 0.090 & 0.134 & 0.349 \\
\hline F-Test on Fixed Effects & - & - & $1.87 * * *$ & - & - & $1.90 * * *$ \\
\hline Observations & 11,317 & 4,430 & 11,463 & 11,308 & 4,430 & 11,453 \\
\hline
\end{tabular}

Notes: For probit models, marginal effects are reported, asymptotic z-values are in parentheses, and the pseudo R-square is reported. For individual fixed effects models, asymptotic t-values are in parentheses, and the adjusted R-square is reported.

Significant at the 1 percent level. 
Table 6

Alcohol Advertising and Alcohol Price Elasticities

\begin{tabular}{|l|c|c|}
\hline Sample & Advertising & Beer Price \\
\hline \multicolumn{3}{|c|}{ MTF Baseline Surveys } \\
\hline Past Year Alcohol Participation \\
\hline Full Sample & 0.021 & -0.130 \\
\hline Whites & 0.020 & -0.188 \\
\hline Blacks & - & -0.117 \\
\hline Males & 0.015 & -0.055 \\
\hline Females & 0.025 & -0.194 \\
\hline \multicolumn{3}{|c|}{} \\
\hline Past Month Alcohol Participation \\
\hline Full Sample & 0.020 & -0.119 \\
\hline Whites & 0.017 & -0.192 \\
\hline Blacks & - & - \\
\hline Males & - & - \\
\hline Females & 0.029 & -0.187 \\
\hline \multicolumn{2}{|c|}{} \\
\hline Past Two-week Binge Participation \\
\hline Full Sample & 0.011 & -0.036 \\
\hline Whites & 0.009 & -0.077 \\
\hline Blacks & 0.013 & - \\
\hline Males & - \\
\hline Females & -0.054 \\
\hline \multicolumn{2}{|c|}{ NLSY 1997 Cohort } \\
\hline Past Month Alcohol Participation \\
\hline Limited Specification & 0.030 & -0.196 \\
\hline Extended Specification & 0.059 & -0.284 \\
\hline Fixed Effects & 0.108 & - \\
\hline \multicolumn{2}{|l|}{} \\
\hline Past Month Binge Participation \\
\hline Limited Specification & 0.038 & -0.202 \\
\hline Extended Specification & 0.107 & -0.508 \\
\hline Fixed Effects & 0.182 & - \\
\hline
\end{tabular}

Notes: Elasticities are calculated at the sample means. The extended specifications in the NLSY97 have a smaller sample size than the limited specification due to missing values. The means used to compute these elasticities are as follows: beer price, 2.43; alcohol advertising, 0.00008; past month alcohol participation, 0.1787; binge participation, 0.0695 . Elasticities are not reported for marginal effects significant at more than 10 percent. 